\title{
0 (NIE)RACJONALNYM USTAWODAWCY NA PRZYKŁADZIE REGULACJI TWORZENIA I ZMIANY GRANIC PARKÓW NARODOWYCH
}

\section{ON (IR)RATIONAL LAWMAKING IN THE LIGHT OF THE PROCEDURE FOR CREATION AND EXPANSION OF NATIONAL PARKS}

http://dx.doi.org/10.12775/PPOS.2014.044

\section{STRESZCZENIE}

Procedura tworzenia i powiększania parków narodowych przewidziana w ustawie o ochronie przyrody z 2004 r. przyznaje samorządowi lokalnemu i regionalnemu uprawnienie do współdecydowania w tej kwestii. Ponadto, na skutek nowelizacji ustawy o ochronie przyrody z 2011 r. utworzenie nowego parku narodowego wymaga zmiany ustawy. Celem artykułu jest wykazanie niezgodności z Konstytucją

" Doktor nauk prawnych, adiunkt w Zakładzie Nauki Administracji na Wydziale Prawa i Administracji Uniwersytetu Warszawskiego. 
przedstawionego powyżej stanu prawnego. Autor opisuje także, jak analizowana regulacja wpłynęła na zatrzymanie rozwoju sieci parków narodowych $\mathrm{w}$ Polsce, pomimo niekwestionowanych potrzeb ekologicznych w tym zakresie.

\section{Słowa kluczowe}

Parki narodowe; obszary chronione; IUCN; samorząd lokalny; ustawa o ochronie przyrody.

\section{ABSTRACT}

The procedure for the creation and expansion of national parks as provided in the Nature Conservation Act of 2004 provides local and regional authorities with the right to co-decide on the issue. In addition, as a result of amendments to the Nature Conservation Act of 2011, the creation of a new national park requires a change in this piece of legislation. The purpose of this article is to demonstrate the unconstitutionality of the above described legal framework. Furthermore, the author presents how the current regulation stopped the development of a network of national parks in Poland, despite the unquestionable environmental needs in this area.

\section{Keywords}

National parks; protected areas; IUCN; local government; Nature Conservation Act.

\section{WPROWADZENIE. ROLA PARKU NARODOWEGO W SYSTEMIE OCHRONY PRZYRODY}

Parki narodowe są najwyższą krajową formą obszarowej i konserwatorskiej ochrony przyrody ${ }^{1}$. Przyjmuje się, że po raz pierwszy ta forma ochrony przyrody pojawiła się w Stanach Zjednoczonych w roku 1872, kiedy utworzono Park Narodowy

1 D. Jakubowska, Ochrona różnorodności biologicznej, [w:] M. Górski (red.), Prawo ochrony środowiska, Warszawa 2009, s. 515. 
Yellowstone ${ }^{2}$. Ogólnie ujmując, idea parku narodowego polega na objęciu szczególnym reżimem prawnym enklaw dzikiej przyrody zabezpieczonych przed ludzką ingerencją, aby zachować ich nienaruszoną formę przyrodniczą. Parki narodowe mają być swoistym bastionem różnorodności biologicznej ${ }^{3}$.

Pierwsze próby stypizowania parku narodowego i innych obszarów chronionych podjęto już w 1933 r. w trakcie Międzynarodowej Konferencji na rzecz Ochrony Fauny i Flory w Londynie $^{4}$. W późniejszym okresie, ważną rolę w upowszechnianiu parku narodowego jako zasadniczej formy ochrony przyrody i tworzeniu standardu ich funkcjonowania odegrały działania Międzynarodowej Unii Ochrony Przyrody (IUCN - International Union for Conservation of Nature), która od 1962 r. zaczęła publikować dokumenty zarówno określające główne typy obszarów chronionych (w szczególności parki narodowe, rezerwaty, pomniki przyrody), jak i zasady ich wyznaczania oraz zarządzania $^{5}$.

Zgodnie z definicją IUCN, park narodowy to „obszar lądowy lub morski poddany ochronie w celu zachowania dla obecnego i przyszłych pokoleń ekologicznych właściwości jednego lub większej liczby ekosystemów, wykluczenia eksploatacji czy zasiedlania w sposób zagrażający realizacji celów ochronnych; zapewnienia warunków dla działalności naukowej, edukacyjnej, rekreacyjnej i turystycznej prowadzonej w sposób spójny

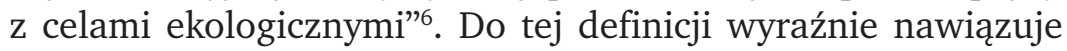

2 P. Van Heijnsbergen, International Legal Protection of Wild Fauna and Flora, Amsterdam 1997, s. 172.

3 A. O. Awiti, Stewardship of national parks and reserves in the era of global change, „Environmental Development” 2012, nr 1, s. 102.

4 A. Philips, The history of the international system of protected area management categories, „Parks” 2004, nr 3, s. 6. Oprócz parków narodowych wyróżniono wówczas również rezerwaty ścisłe, rezerwaty fauny i flory oraz rezerwaty z zakazem polowania i zbieractwa. Klasyfikacja była powszechnie stosowana przez mocarstwa kolonialne w Afryce Subsaharyjskiej.

5 N. Dudley (red.), Guidelines for Applying Protected Area Management Categories, Gland 2008, s. 3 i nast.

6 Oryg. „Natural area of land and/or sea, designated to (a) protect the ecological integrity of one or more eco systems for present and future generations, (b) exclude exploitation or occupation inimical to the purposes of 
ujęcie parku narodowego w polskim ustawodawstwie. Artykuł 8 ust. 1 ustawy o ochronie przyrody ${ }^{7}$ stanowi bowiem, że: „Park narodowy obejmuje obszar wyróżniający się szczególnymi wartościami przyrodniczymi, naukowymi, społecznymi, kulturowymi i edukacyjnymi, o powierzchni nie mniejszej niż 1000 ha, na którym ochronie podlega cała przyroda oraz walory krajobrazowe". Celem utworzenia i działania parku jest natomiast „zachowanie różnorodności biologicznej, zasobów, tworów i składników przyrody nieożywionej i walorów krajobrazowych, przywrócenia właściwego stanu zasobów i składników przyrody oraz odtworzenie zniekształconych siedlisk przyrodniczych, siedlisk roślin, siedlisk zwierząt lub siedlisk grzybów" (art. 8 ust. 2 u.o.p.). Oznacza to poddanie ochronie na terytorium parku całej przyrody i walorów krajobrazowych danego terenu, co przekłada się na najszerszy zakres ochrony przysługującej obszarom objętym parkami narodowymi ${ }^{8}$.

Adekwatnie do pozycji parków narodowych w krajowym systemie ochrony przyrody, ustawodawca przewidział daleko idące konsekwencje prawne objęcia danego obszaru tą formą ochrony. Po pierwsze, jest to jedyna forma ochrony przyrody, która w całości musi być realizowana na obszarze należącym do Skarbu Państwa. W przypadku rozciągnięcia granic parku na nieruchomości nienależące do Skarbu Państwa, istnieje obowiązek ich nabycia, a w braku zgody właściciela - wywłaszczenia9 . Po drugie, przepisy u.o.p. określają szczególny reżim prawny obowiązujący na obszarze parku narodowego, którego podstawowymi cechami są zakazy i ograniczenia dotyczące zarówno

designation of the area and (c) provide a foundation for spiritual, scientific, educational, recreational and visitor opportunities, all of which must be environmentally and culturally compatible." IUCN World Commission on Protected Areas with the assistance of the World Conservation Monitoring Centre, Guidelines for Protected Area Management Categories, 1994, s. 19.

7 Ustawa z dnia 16 kwietnia 2004 r. o ochronie przyrody, t.j. Dz.U. z 2013 r., poz. 627 ze zm. (dalej: u.o.p.).

8 B. Rakoczy, Prawo ochrony przyrody, Warszawa 2009, s. 31.

9 Art. 7 ust. 2 u.o.p. 
wstępu na teren parku, jak i prowadzenia tam jakiejkolwiek aktywności ${ }^{10}$.

\section{ROZWÓJ SIECI PARKÓW NARODOWYCH W POLSCE}

Obecnie w Polsce istnieją 23 parki narodowe, które zajmują powierzchnię 316748 ha, co stanowi ok. 1\% powierzchni $\mathrm{kraju}^{11}$. Jest to obszar relatywnie mały, jeśli porównać go z innymi państwami europejskim ${ }^{12}$. Pierwszy polski park narodowy to Pieniński PN utworzony rozporządzeniem Ministra Rolnictwa z 23 maja 1932 r. ${ }^{13}$ Przed II wojną światową powołano do życia jeszcze tylko Białowieski PN ${ }^{14}$. W okresie PRL-u okres największej aktywności w rozwoju sieci parków narodowych przypadł na lata pięćdziesiąte, kiedy powstały Świętokrzyski PN (1950), Tatrzański i Babiogórski PN (1954), Narwiański i Ojcowski PN (1956) Wielkopolski PN (1957) oraz Kampinoski i Karkonoski PN (1959). Po powołaniu w 1960 r. Wolińskiego PN nastąpił kilkuletni zastój przerwany w 1967 r. utworzeniem Słowińskiego PN. W latach siedemdziesiątych do listy parków narodowych dołączono Bieszczadzki PN (1973) oraz Roztoczański PN (1974). W kolejnej dekadzie powstały jeszcze Gorczański PN (1981) oraz Wigierski PN (1989).

Można było oczekiwać, że utworzenie WPN zwiastować będzie ożywienie w polityce ekologicznej państwa, związane

10 Zob. w szczególności art. 12 i art. 15 u.o.p.

11 Dane GUS (Mały rocznik statystyczny 2012).

12 Przykładowo, w Wielkiej Brytanii zajmują one ponad 8 proc. powierzchni kraju (dane za: http://www.nationalparks.gov.uk/), w Niemczech - ponad 2 proc. (dane za: http://www.bfn.de).

13 Rozporządzenie Ministra Rolnictwa z dnia 23 maja 1932 r. o utworzeniu z rezerwatu w Pieninach jednostki organizacyjnej szczególnej pod nazwą „Park Narodowy w Pieninach”, M.P. z 1932 r., Nr 123, poz. 156.

14 Rozporządzenie Ministra Rolnictwa i Reform Rolnych z dnia 4 sierpnia 1932 r. o utworzeniu z Nadleśnictwa Rezerwat w okręgu Dyrekcji Lasów Państwowych w Białowieży jednostki organizacyjnej szczególnej pod nazwą „Park Narodowy w Białowieży", M.P. z 1932 r., Nr 183, poz. 219. 
również z przemianami ustrojowymi. Umożliwiły one aktywne działania ze strony organizacji ekologicznych i ekspertów, którzy mogli już w sposób otwarty wyrażać postulaty pod adresem władzy publicznej i wywierać presję na rzecz podjęcia działań rekompensujących zaniedbania okresu PRL-u, w tym uzupełnienie siatki parków narodowych. Oczekiwania te spełniły się tylko częściowo. W 1990 r. powstał Drawieński oraz Poleski PN, następnie w 1993 r. - Park Narodowy Gór Stołowych i Biebrzański Park Narodowy. Istotne zmiany na mapie parków narodowych nastąpiły w latach 1995-1996, kiedy to powołano do życia trzy kolejne parki - Magurski PN, PN Bory Tucholskie i Narwiański PN. Następnie, po pięcioletniej przerwie utworzono PN Ujścia Warty (2001), po czym rozpoczął się zastój, pomimo ciągle zgłaszanych postulatów tworzenia kolejnych parków. W latach 2001-2010 nie utworzono żadnego nowego parku narodowego.

Podobną dynamikę można zaobserwować, gdy chodzi o powiększanie obszaru parków narodowych. Ogółem w latach 1990-2010 zmiany granic parków narodowych poprzez ich rozszerzenie dokonano 20 razy. Zdecydowanie najbardziej aktywny okres przypadł na lata 1996-1997, kiedy przeprowadzono 13 operacji rozszerzenia parków narodowych. Po raz ostatni zwiększono powierzchnię parków narodowych w kwietniu 2004 r., kiedy to o ponad 14 tys. ha poszerzono granice Słowińskiego PN. Od tego momentu proces rozszerzania obszaru parków narodowych zamarł.

Powyższe dane ilustrują wyraźną tendencję w kwestii powiększania obszaru parków narodowych w Polsce na przestrzeni ostatnich dwóch dekad. Zarówno jeśli chodzi o tworzenie nowych, jak i zmianę granic już istniejących parków narodowych, okres najwyższej aktywności przypadł na lata dziewięćdziesiąte poprzedniego stulecia, ze szczególnym uwzględnieniem lat 1995-1997. Najbardziej jednak uderza całkowite zamrożenie procesu rozszerzania obszaru objętego parkami narodowymi po 2004 r., a w zasadzie nawet już od 2001 r., kiedy to po raz ostatni utworzono nowy park narodowy. 


\section{PRZEOBRAŻENIA REGULACJI TWORZENIA I ZMIANY GRANIC PARKÓW NARODOWYCH}

Śledząc losy zmian w procedurze tworzenia i powiększania parków narodowych, można zidentyfikować przyczynę zatrzymania tego procesu po 2001 r. Załamanie rozwoju sieci parków narodowych w Polsce zbiegło się z istotną zmianą reżimu prawnego tworzenia parków narodowych wprowadzoną ustawą z dnia 7 grudnia $2000 \mathrm{r}$. o zmianie ustawy o ochronie przyrody, która weszła w życie w dniu 2 lutego 2001 r. ${ }^{15}$ Przed wejściem w życie noweli z grudnia 2000 r., procedura tworzenia i powiększania granic parków narodowych opierała się na jednostronnym i w pełni samodzielnym rozstrzygnięciu Rady Ministrów podejmowanym w drodze rozporządzenia. Był to reżim, który do uchwalonej 1991 r. nowej ustawy o ochronie przyrody $^{16}$, przeniesiono bez istotnych modyfikacji z ustawy obowiązującej w okresie Polski Ludowej (ustawa o ochronie przyrody z 1949 r. $^{17}$ ). W tym trybie - obowiązującym przez niespełna dekadę (grudzień 1991-luty 2001) - udało się utworzyć pięć nowych parków i osiemnastokrotnie powiększyć powierzchnię już istniejących.

Nowelizacja u.o.p. z 7 grudnia 2000 r. zawierała wiele zmian, które zostały ocenione krytycznie jako osłabiające poziom ochrony przyrody w Polsce. Skutkiem nowelizacji była m.in. utrata mocy obowiązującej planów ochrony dla parków narodowych, głównego określającego cele i zadania związane z zapewnieniem odpowiedniego stanu zasobów przyrodniczych w parkach narodowych ${ }^{18}$.

15 Ustawa z dnia 7 grudnia 2000 r. o zmianie ustawy o ochronie przyrody, Dz.U. z 2001 r., Nr 3, poz. 21.

16 Ustawa z dnia 16 października 1991 r. o ochronie przyrody, Dz.U. z 1991 r., Nr 114, poz. 492.

17 Ustawa z dnia 7 kwietnia 1949 r. o ochronie przyrody, Dz.U. z 1949 r., Nr 25, poz. 180.

18 M. Gwiazdowicz, Ochrona przyrody $w$ Polsce. Wybrane problemy, Raport Biura Studiów i Ekspertyz Kancelarii Sejmu RP, Warszawa 2002, s. 5; W. Ra- 
W kwestii tworzenia i powiększania parków narodowych nowela również przyniosła drastyczne zmiany. W art. 14 u.o.p. z 1991 r. regulującym procedurę tworzenia i powiększania parków narodowych wprowadzono bowiem ust. 7b, zgodnie z którym: „Utworzenie, powiększenie, zmniejszenie lub likwidacja parku narodowego może nastąpić tylko po uzgodnieniu z właściwymi miejscowo organami zainteresowanych jednostek samorządu terytorialnego, na których obszarze działania planuje się powyższe zmiany, oraz po zaopiniowaniu, w terminie jednego miesiąca od dnia przedłożenia tych zmian, przez zainteresowane organizacje pozarządowe. Niezłożenie opinii w przewidzianym terminie uznaje się za brak uwag".

W procesie decyzyjnym pojawił się zatem dodatkowy aktor o statusie w istocie równoprawnym do Rady Ministrów, która do tej pory jako jedyna wyposażona była w kompetencje decyzyjne. Formuła uzgodnienia oznacza bowiem konieczność uzyskania wyraźnej aprobaty organów upoważnionych do uzgodnienia dla projektu przedłożonego przez Radę Ministrów. Brak stanowiska upoważnionych organów nie może być też poczytywany jako wyrażenie zgody w sposób dorozumiany. Co więcej, ustawa, posługując się klauzulą „zainteresowanych jednostek samorządu terytorialnego", włączyła w całą procedurę szeroki krąg organów. Gdy mowa o zainteresowanych jednostkach samorządu terytorialnego należy bowiem przez to rozumieć nie tylko gminy, na obszarze których mają być zlokalizowane nowe obszary parkowe, ale także powiaty i województwa. W minimalnym wariancie wymagana jest zatem zgoda trzech organów (rada gminy, rada powiatu, sejmik województwa), choć z reguły konieczne będzie zaangażowanie organów stanowiących większej liczby jednostek samorządu terytorialnego (np. rad kilku gmin).

Zacytowany przepis $\mathrm{w}$ niezmienionym brzmieniu zachowano w nowej u.o.p. z 2004 r. jako art. 10 ust. 2. Istotną modyfikację przyniosła jednak obszerna nowelizacja u.o.p. z sierpnia

decki, Ochrona prawna parków narodowych przez zagrożeniami zewnętrznymi, „Prądnik. Prace Muzeum Szafera” 2007, tom 17, s. 31. 
2011 r. ${ }^{19}$ Rozdzieliła ona proces tworzenia od powiększania parków narodowych. W związku z tym, w obecnym stanie prawnym określenie i zmiana granic parku narodowego następuje w drodze rozporządzenia Rady Ministrów po uzgodnieniu z właściwymi miejscowo organami uchwałodawczymi jednostek samorządu terytorialnego, na których obszarze działania planuje się powyższe zmiany ${ }^{20}$. Ustawa milczy na temat procedury utworzenia parku narodowego, jednak z nowego brzmienia art. 10 ust. 3 u.o.p. można wnioskować, że wymaga to zmiany u.o.p. Przepis ten posługuje się bowiem pojęciem „ustawy o utworzeniu parku narodowego". Ponadto, do u.o.p. wprowadzono załącznik zawierający wykaz parków narodowych, z czego można by wnosić, że utworzenie nowego parku nastąpić powinno w drodze uzupełnienia owego załącznika. Należy jednak podkreślić brak jednoznacznego określenia kompetencji oraz trybu procedowania w kwestii utworzenia parku narodowego.

\section{REGULACJA TWORZENIA I ZMIANY GRANIC PARKÓW NARODOWYCH W ŚWIETLE STANDARDÓW KONSTYTUCYJNYCH}

Obowiązująca od 2001 r. (z modyfikacjami wprowadzonymi w 2011 r.) procedura tworzenia i zmiany granic parków narodowych winna podlegać analizie zarówno z punktu widzenia polityki prawa, jak i poprawności legislacyjnej.

Definiując politykę prawa jako „używanie prawa do osiągania założonych celów"21, nie można pominąć korelacji między procedurą tworzenia i zmiany granic parków wprowadzoną nowelą grudniową z 2000 r. a zatrzymaniem rozwoju sieci parków narodowych w Polsce. Należy również wziąć pod uwagę bogatą historię nieudanych prób powiększenia istniejących parków lub

19 Ustawa z dnia 18 sierpnia 2011 r. o zmianie ustawy o ochronie przyrody oraz niektórych innych ustaw, Dz.U. z 2011 r., Nr 224, poz. 1337.

20 Art. 10 ust. 1 i 2 u.o.p.

21 J. Wróblewski, Zasady tworzenia prawa, Warszawa 1989, s. 36. 
utworzenia nowych pod rządami regulacji obowiązującej już od ponad dekady ${ }^{22}$. Tymczasem, cele polityki państwa (polityki prawa) w tej dziedzinie zostały dość precyzyjnie określone w kluczowych dokumentach strategicznych, m.in. w „Polityce ekologicznej państwa w latach 2009-2012 z perspektywą do 2016 r.” oraz „Krajowej strategii ochrony i zrównoważonego użytkowania różnorodności biologicznej” z 2007 r. W dokumentach tych wskazano, że: „Jest ważna także kontynuacja tworzenia krajowej sieci obszarów chronionych uwzględniająca utworzenie nowych parków narodowych, rezerwatów, parków krajobrazowych oraz powstanie form i obiektów ochrony przyrody”23. Za priorytet uznano „powołanie Turnickiego PN, Jurajskiego PN, Mazurskiego PN, powiększenie Białowieskiego PN i Karkonoskiego PN" ${ }^{24}$. Brak realizacji tych celów, pomimo podejmowanych prób, świadczyć może o nieadekwatnym i nieskutecznym uregulowaniu kwestii tworzenia i powiększania parków narodowych.

Analizowanej regulacji postawić można jednak również zarzuty wykraczające poza nieefektywność. W pierwszej kolejności stawiam tezę, że może ona naruszać konstytucyjne zasady prowadzenia polityki państwa (ściślej: polityki ekologicznej) oraz podziału odpowiedzialności w tej sferze. Konstytucja Rzeczypospolitej Polskiej z 1997 r. $^{25}$ zawiera szereg postanowień istotnych dla zasad prowadzenia polityki ekologicznej państwa. Problemom ochrony środowiska ustrojodawca nadał niezwykle wysoką rangę. Obowiązek działania państwa na rzecz ochrony środowiska został bowiem wyeksponowany już jako jedna z zasad ustroju państwa wskazanych w rozdziale pierwszym Kon-

${ }^{22}$ Najbardziej spektakularnym niepowodzeniem zakończyły się próby powiększenia Białowieskiego Parku Narodowego.

23 Ministerstwo Środowiska, Polityka ekologiczna państwa w latach 2009-2012 z perspektywa do 2016, Warszawa 2008, s. 26-27.

24 Rada Ministrów RP, Krajowa strategia ochrony i zrównoważonego użytkowania różnorodności biologicznej oraz Program Działań na lata 2007-2013. Załącznik do uchwały nr 270/2007 Rady Ministrów z dnia 26.10.2007 r., s. 65.

25 Konstytucja Rzeczpospolitej Polskiej z dnia 2 kwietnia 1997 r., Dz.U. z 1997 r., Nr 78, poz. 483 z późn. zm. 
stytucji. Zgodnie z art. 5 ustawy zasadniczej ${ }^{26}$ : „Rzeczpospolita Polska strzeże niepodległości i nienaruszalności swojego terytorium, zapewnia wolności i prawa człowieka i obywatela oraz bezpieczeństwo obywateli, strzeże dziedzictwa narodowego oraz zapewnia ochronę środowiska, kierując się zasadą zrównoważonego rozwoju".

Dalej, ochrona środowiska jest również jednym z nielicznych obowiązków obywatelskich wprost wymienionych w Konstytucji. Według art. 86: „Każdy jest obowiązany do dbałości o stan środowiska i ponosi odpowiedzialność za spowodowane przez siebie jego pogorszenie". Ochrona środowiska stanowi również jedną z przesłanek, dla których realizacji możliwe jest wprowadzanie ograniczeń w korzystaniu z konstytucyjnych wolności i praw (art. 31 ust. 3 Konstytucji RP). Niezwykle istotne znaczenie odgrywa art. 74 Konstytucji, który zobowiązuje władze publiczne do prowadzenia polityki zapewniającej „bezpieczeństwo ekologiczne współczesnemu i przyszłym pokoleniom". Ponadto, przepis ten - niezależnie od cytowanego wyżej art. 5 Konstytucji RP - ponownie podkreśla, że: „Ochrona środowiska jest obowiązkiem władz publicznych".

Ustawa zasadnicza nie tylko jednak tworzy solidne fundamenty ustrojowe dla działań państwa na rzecz ochrony cennych zasobów przyrodniczych. Równie ważnym elementem regulacji konstytucyjnej są przepisy dotyczące rozdziału zadań, kompetencji i sfer odpowiedzialności pomiędzy organami władzy publicznej. Generalnemu przypisaniu wszystkim organom państwa obowiązku działania na rzecz ochrony środowiska towarzyszyć powinno jasne i precyzyjne określenie kto, za co i w jakim zakresie ponosi odpowiedzialność.

Ustalenie sfer odpowiedzialności i kompetencji jest możliwe zwłaszcza dzięki szczegółowemu uregulowaniu zadań Rady

$26 \mathrm{Na}$ temat interpretacji konstytucyjnej zasady ochrony środowiska i zrównoważonego rozwoju zob. szerzej: M. Stoczkiewicz, Zasada zrównoważonego rozwoju jako zasada prawa, „Prawo i Środowisko” 2001, nr 1; Z. Bukowski, Konstytucyjne podstawy obowiązków państwa $w$ zakresie ochrony środowiska, „Prawo i Środowisko” 2002, nr 4; P. Sarnecki, Uwagi do art. 5, [w:] L. Garlicki (red.), Konstytucja Rzeczypospolitej Polskiej. Komentarz, Warszawa 2001. 
Ministrów. Otóż, stosownie do art. 146 Konstytucji „Rada Ministrów prowadzi politykę wewnętrzną i zagraniczną Rzeczypospolitej Polskiej”. Ponadto, „do Rady Ministrów należą sprawy polityki państwa nie zastrzeżone dla innych organów państwowych i samorządu terytorialnego". Wśród szczegółowych zadań Rady Ministrów wymienia się m.in. zapewnienie bezpieczeństwa wewnętrznego państwa, co w szerokim sensie obejmuje zapewne również bezpieczeństwo ekologiczne rozumiane jako ochrona najcenniejszych zasobów przyrodniczych kraju. Przekładając zacytowane klauzule dotyczące zakresu odpowiedzialności rządu na pole polityki ekologicznej państwa, można przyjąć, że misją rządu jest podejmowanie działań o najszerszym zasięgu i największej wadze dla realizacji przez państwo konstytucyjnego obowiązku ochrony środowiska. Obejmuje to działania kluczowe dla realizacji polityki wewnętrznej państwa w tym obszarze, mające również na celu zapewnienie bezpieczeństwa ekologicznego.

Takie założenie winno znaleźć odzwierciedlenie w poszczególnych obszarach polityki ekologicznej. Jedną z najważniejszych sfer jest tworzenie i zarządzanie formami ochrony przyrody (głównie formy ochrony obszarowej) wymienionymi w art. 6 u.o.p. Każdej z form ochrony przyrody winien być wyraźnie przypisany organ władzy publicznej odpowiedzialny za zapewnienie jej właściwego funkcjonowania. Podział odpowiedzialności powinien zaś być pochodną rangi danej formy, jej zakresu oraz wymogów w kwestii zarządzania. Ustawodawca w znacznym zakresie to założenie respektuje. W związku z tym, parki krajobrazowe i obszary chronionego krajobrazu pozostają w sferze odpowiedzialności samorządu regionalnego współdziałającego z samorządem lokalnym ${ }^{27}$ albo terenową administracją rządową ${ }^{28}$, rezerwaty przyrody - terenowej administracji

27 Park krajobrazowy tworzy sejmik województwa po uzyskaniu zgody właściwej rady gminy oraz właściwego regionalnego dyrektora ochrony środowiska.

28 O utworzeniu obszaru chronionego krajobrazu decyduje sejmik województwa po uzyskaniu zgody właściwego regionalnego dyrektora ochrony środowiska. 
rządowej29 ${ }^{29}$ zaś obszary Natura 2000 - centralnej administracji rządowej działającej w porozumieniu z Komisją Europejską ${ }^{30}$.

Jedynie w przypadków parków narodowych mamy do czynienia $\mathrm{z}$ procedurą wymagają współdecydowania wszystkich szczebli władzy publicznej - począwszy od samorządu lokalnego (gminy i powiaty), poprzez samorząd regionalny (województwo samorządowe), centralną administrację rządową (Radę Ministrów), na parlamencie skończywszy. O ile zaangażowanie parlamentu, biorąc pod uwagę rangę zagadnienia oraz jego ogólnopaństwowy charakter, można zrozumieć, to przyznanie organom jednostek samorządu terytorialnego kompetencji kodecyzyjnych w sprawach polityki państwa, dotykających interesu publicznego w skali ogólnopaństwowej oraz kluczowych dla realizacji polityki ekologicznej państwa należy poczytywać jako naruszenie konstytucyjnej konstrukcji sfer odpowiedzialności poszczególnych organów władzy publicznej. W szczególności przyjęte w 2000 r. rozwiązanie pozostaje w kolizji z konstytucyjnym zakresem odpowiedzialności Rady Ministrów (art. 146 Konstytucji RP). Nie stanowi również realizacji wyrażonej w Preambule zasady pomocniczości oraz innych gwarancji decentralizacji władzy publicznej, ponieważ przyznaje organom jednostek samorządu terytorialnego kompetencje daleko wykraczające poza sprawny publiczne o znaczeniu lokalnym czy regionalnym.

W tym kontekście należy się odnieść do wyroku Trybunału Konstytucyjnego z dnia 13 maja 2009 r. ${ }^{31}$, który może być w kontekście analizowanego problemu uznany za istotny. Jego przedmiotem była ocena zgodności z art. 5 Konstytucji RP przepisów ustawy o ochronie przyrody wyposażających samorząd województwa w kompetencje do tworzenia i likwidacji parków krajobrazowych. Trybunał orzekł o zgodności kwestionowanych

29 Rezerwaty przyrody tworzy właściwy regionalny dyrektor ochrony środowiska.

30 Utworzenie obszaru Natura 2000 należy do kompetencji Ministra Środowiska za zgodą Rady Ministrów oraz w uzgodnieniu z Komisją Europejską.

31 Wyrok Trybunału Konstytucyjnego z dnia 13 maja 2009 r., Kp 2/09, OTK 2009/5A/66. 
przez Prezydenta RP przepisów z przywołanym wzorcem konstytucyjnym. Treść tego wyroku nie podważa jednak w żadnym stopniu przedstawionych wyżej konkluzji. W pierwszej kolejności należy zauważyć, że przedmiotem sporu konstytucyjnego była procedura tworzenia parków krajobrazowych. Jakakolwiek analogia do parków narodowych nie byłaby tu uzasadniona, zważywszy na odmienny cel, status czy reżim prawny obowiązujący dla tych form ochrony przyrody. Nie można wykluczać, że kompetencje decyzyjne samorządu $\mathrm{w}$ dziedzinie tworzenia parków krajobrazowych pozostają w zgodzie z konstytucyjnymi regułami dystrybucji kompetencji między rząd i samorządy. Ponadto, trzeba pamiętać, że wniosek Prezydenta RP był o tyle niekompletny, że jako jedyny wzorzec kontroli konstytucyjności wskazywał art. 5 Konstytucji RP. Sprawa rozpatrywana przez TK nie dotyczyła zatem w ogóle oceny regulacji dotyczącej parków krajobrazowych z przepisami ustawy zasadniczej dotyczącymi kompetencji rządu. Co ciekawe jednak, nawet przy braku podstaw do zakwestionowania zaskarżonego przepisu Trybunał nie powstrzymał się od ich krytycznej oceny. Wskazał, że: „Uchwalone rozwiązania mogą być uznane za dyskusyjne i można wyrażać wątpliwości, czy wprowadzany model jest lepszy od funkcjonującego dotychczas albo czy pozwala chronić środowisko w sposób optymalny".

Marginesowo można również wytknąć ustawodawcy niekonsekwencję. Skoro bowiem zapewniono jednostkom samorządu terytorialnego kompetencje decyzyjne $\mathrm{w}$ procesie tworzenia i zmiany granic parków narodowych, logicznym byłoby przeniesienie tej formuły również na etap zarządzania parkiem. Tymczasem, rola samorządów w bieżącym zarządzaniu parkiem jest marginalna i sprowadza się właściwie do zaopiniowania planu ochrony, jednakże bez wpływu na jego treśćc ${ }^{32}$ oraz udziału w pracach rady parku narodowego (organ opiniodawczo-dorad(zzego) ${ }^{33}$.

Nowelizacja u.o.p. z 2011 r. pogłębiła jeszcze powyższe wątpliwości konstytucyjne. Jej rezultatem jest bowiem niepre-

32 Art. 19 u.o.p.

33 Art. 98 u.o.p. 
cyzyjna procedura tworzenia parku narodowego, która może w ten sposób naruszać zasady poprawnej legislacji wywodzone z konstytucyjnej zasady demokratycznego państwa prawnego (art. 2 Konstytucji RP). Zgodnie z utrwalonym orzecznictwem Trybunału Konstytucyjnego, jednym z komponentów zasady demokratycznego państwa prawnego jest postulat określoności przepisów prawa jako gwarancja ochrony zaufania obywatela do państwa i stanowionego przez nie prawa. Jakkolwiek zasada ta odnosi się szczególnie do sfery władczej ingerencji państwa w wolności i prawa jednostki ${ }^{34}$, znaczenie generalne należy nadać postulatowi konstruowania przepisów prawnych w sposób poprawny, precyzyjny i jasny. Jak to wyłożył TK w wyroku z 21 marca 2001 r.: „Z tak ujętej zasady określoności wynika, że każdy przepis prawny winien być skonstruowany poprawnie z punktu widzenia językowego i logicznego - dopiero spełnienie tego warunku podstawowego pozwala na jego ocenę w aspekcie pozostałych kryteriów. Wymóg jasności oznacza nakaz tworzenia przepisów klarownych i zrozumiałych dla ich adresatów, którzy od racjonalnego ustawodawcy oczekiwać mogą stanowienia norm prawnych nie budzących wątpliwości co do treści nakładanych obowiązków i przyznawanych praw. Związana z jasnością precyzja przepisu winna przejawiać się w konkretności nakładanych obowiązków i przyznawanych praw tak, by ich treść była oczywista i pozwalała na wyegzekwowanie"35.

Tymczasem, opisana wyżej procedura tworzenia parków narodowych rodzi niejasności w jej fundamentalnych aspektach - zarówno trybu, jak i organu upoważnionego do działania. Przede wszystkim zaś brak jest wyraźnej, jednoznacznej normy kompetencyjnej w tym zakresie. Jak już przeanalizowano wyżej, brzmienie art. 10 ust. 3 u.o.p. oraz ujęcie listy parków narodo-

34 Por. np. wyroki Trybunału Konstytucyjnego z dnia 21 marca 2001 r., K 24/00, z dnia 11 maja 2004 r., K 4/03 oraz z dnia 17 maja 2006 r., K 33/05. Zob. szerzej: Biuro Trybunału Konstytucyjnego, Proces prawotwórczy $w$ świetle orzecznictwa Trybunału Konstytucyjnego. Wypowiedzi Trybunału Konstytucyjnego dotyczące zagadnień związanych z procesem legislacyjnym, Warszawa 2012, s. 49-74.

35 Wyrok Trybunału Konstytucyjnego z dnia 21 marca 2001 r., K 24/00, OTK 2001/3/51. 
wych w załączniku do u.o.p. mogłoby wskazywać, że utworzenie nowego parku narodowego w obecnym stanie prawnym nastąpić może poprzez zmianę treści załącznika do u.o.p. i w taki sposób należy rozumieć pojęcie „ustawy o utworzeniu parku narodowego", którym posłużono się w art. 10 ust. 3 u.o.p. Takiej konstrukcji daleko jednak do precyzyjności, jasności i poprawności. Ponadto, nawet przyjmując taką wykładnię za właściwą, należy zwrócić uwagę na brak realnego znaczenia aktu ustawodawczego o utworzeniu parku narodowego. Ustawa w sprawie utworzenia parku narodowego określa bowiem w istocie jedynie jego nazwę, zaś ustalenie jego obszaru następuje w drodze rozporządzenia Rady Ministrów z uwzględnieniem procedury uzgodnieniowej z odpowiednimi jednostkami samorządu terytorialnego. Do tego czasu park narodowy pozostaje tworem „wirtualnym”. Nie jest nawet jasne, czy dla tak utworzonego, ale nieposiadającego ustalonego obszaru parku należy powoływać dyrektora i inne organy. Wydaje się, że tego typu pytania i niekiedy absurdalne konsekwencje obecnej regulacji można mnożyć.

\section{KONKLUZJE}

Przedstawione powyżej zastrzeżenia względem obecnej regulacji tworzenia i zmiany granic powiększania parków narodowych można ująć w dwa główne zarzuty. Pierwszy z nich dotyczy wadliwej formuły partycypacji lokalnej w decydowaniu o sprawach dotyczących parku narodowego. Udział samorządu lokalnego i regionalnego $\mathrm{w}$ procedurze tworzenia i powiększania parku narodowego wydaje się pożądany, jako że decyzja taka pociąga za sobą istotne skutki finansowe, społeczne czy gospodarcze. Partycypacja wspólnot lokalnych powinna się jednak odbywać w ramach konstytucyjnego modelu podziału sfer odpowiedzialności poszczególnych organów władzy publicznej. Przyznanie prawa współdecydowania o utworzeniu i ustaleniu granic parku narodowego prowadzi jednak do naruszenia konstytucyjnych kompetencji Rady Ministrów w zakresie prowadze4/2014 nia polityki ekologicznej państwa. 
Drugi zarzut dotyczy braku jednoznacznie określonej procedury tworzenia parku narodowego. Jak się wydaje, występuje tutaj luka konstrukcyjna rozumiana jako sytuacja, w której „normy danego systemu przewidują dokonywanie jakichś czynności konwencjonalnych (...), ale w systemie tym brak reguł wskazujących, jak ważnie dokonać owych czynności, czy też reguły te są nie dość precyzyjne ${ }^{36}$ ". Luka ta polega na nieprecyzyjnym i niejasnym określeniu trybu i organu upoważnionego do utworzenia parku narodowego. Skala niejasności oraz ustawodawczych niedociągnięć $\mathrm{w}$ tym zakresie prowadzić może do naruszenia wywodzonych z zasady demokratycznego państwa prawnego (art. 2 Konstytucji RP) reguł poprawnej legislacji.

Nie ulega wątpliwości, że obecny stan prawny wymaga pilnej sanacji nie tylko przez wzgląd na wątpliwości natury konstytucyjnej, ale przede wszystkim z uwagi na niekwestionowane cele przyrodnicze, które de lege lata nie mogą być skutecznie realizowane.

\section{BIBLIOGRAFIA}

Awiti A.O., Stewardship of national parks and reserves in the era of global change, „Environmental Development” 2012, nr 1.

Biuro Trybunału Konstytucyjnego, Proces prawotwórczy $w$ świetle orzecznictwa Trybunatu Konstytucyjnego. Wypowiedzi Trybunatu Konstytucyjnego dotyczące zagadnień zwiąanych z procesem legislacyjnym, Warszawa 2012.

Bukowski Z., Konstytucyjne podstawy obowiązków państwa $w$ zakresie ochrony środowiska, „Prawo i Środowisko” 2002, nr 4.

Dudley N. (red.), Guidelines for Applying Protected Area Management Categories, Gland 2008.

Gwiazdowicz M., Ochrona przyrody w Polsce. Wybrane problemy, Raport Biura Studiów i Ekspertyz Kancelarii Sejmu RP, Warszawa 2002.

36 S. Wronkowska, Podstawowe pojęcia prawa i prawoznawstwa, Poznań 2005, s. 105. 
IUCN World Commission on Protected Areas with the assistance of the World Conservation Monitoring Centre, Guidelines for Protected Area Management Categories, 1994.

Jakubowska D., Ochrona różnorodności biologicznej, [w:] Górski M. (red.), Prawo ochrony środowiska, Warszawa 2009.

Ministerstwo Środowiska, Polityka ekologiczna państwa $w$ latach 2009-2012 z perspektywa do 2016, Warszawa 2008.

Philips A., The history of the international system of protected area management categories, „Parks” 2004, nr 3.

Rada Ministrów RP, Krajowa strategia ochrony $i$ zrównoważonego użytkowania różnorodności biologicznej oraz Program Działań na lata 2007-2013. Załącznik do uchwały nr 270/2007 Rady Ministrów z dnia 26.10.2007 r.

Radecki W., Ochrona prawna parków narodowych przez zagrożeniami zewnętrznymi, „Prądnik. Prace Muzeum Szafera” 2007, tom 17.

Rakoczy B., Prawo ochrony przyrody, Warszawa 2009.

Sarnecki P., Uwagi do art. 5 [w:] Garlicki L. (red.), Konstytucja Rzeczypospolitej Polskiej. Komentarz, Warszawa 2001.

Stoczkiewicz M., Zasada zrównoważonego rozwoju jako zasada prawa, „Prawo i Środowisko” 2001, nr 1.

Van Heijnsbergen P., International Legal Protection of Wild Fauna and Flora, Amsterdam 1997.

Wróblewski J., Zasady tworzenia prawa, Warszawa 1989.

Wronkowska S., Podstawowe pojęcia prawa i prawoznawstwa, Poznań 2005.

Kontakt e-mail:

dawid.szescilo@uw.edu.pl 